\title{
Wild edible plants in the Ehotilé, a fishing people around Aby lagoon (eastern littoral of Côte d'Ivoire): Knowledge and availability
}

\author{
Malan Djah Francois* \\ UFR Sciences Sciences de la Nature, Université Nangui Abrogoua , 08 Bp 109 Abidjan 08, \\ République de Côte d'Ivoire \\ Neuba Danho Fursy Rodelec \\ UFR Sciences Sciences de la Nature, Université Nangui Abrogoua , 08 Bp 109 Abidjan 08, \\ République de Côte d'Ivoire \\ *Corresponding author. Email: malandf@gmail.com
}

\section{Article Info}

https://doi.org/10.31018/

jans.v13i1.2467

Received: December 23, 2020

Revised: January 30, 2021

Accepted: February 6, 2021

\section{How to Cite}

Malan, D.F. and Neuba, D.F.R (2021). Wild edible plants in the Ehotilé, a fishing people around Aby lagoon (eastern littoral of Côte d'Ivoire): Knowledge and availability. Journal of Applied and Natural Science, 13(1): 59 - 70. https:// doi.org/10.31018/jans.v13i1.2467

\begin{abstract}
This study is set within the important framework of the imperative need to safeguard traditional knowledge at historical, nutritional levels, and as an element of sustainable management of natural resources. Thus, it aimed to identify, through four ethnobotanical surveys (2007, 2009, 2015 and 2019), the wild edible plants used by the Ehotile around the Aby Lagoon, on the Ivorian eastern littoral, to evaluate the use, preference and availability related to these plants and to discuss the evolution of food practices since the observations of missionaries three centuries earlier. The level of knowledge was analysed using Smith's Index and the availability of edible fruits was assessed with a new cognitive index. Compared to the era of the first settlement, the diet of the Ehotile has undergone many modifications. Current observations showed that wild plants were rarely used in the diet which was essentially cassava-based. Thirty-nine edible ethnospecies corresponding to 40 scientific plants species were recorded for 46 uses, of which, wild fruits with $54.17 \%$ were the most important. Edible fruits were available all year round, but irregularly and the availability index suggested that 10 species of the fruits sought were rare in the region. The study has shown that gathering plants are well known by the Ehotilé. However, they are not very present in their diet. In addition, they have a good knowledge of the availability of their edible plants and could therefore be key resource persons in any assessment of the dynamics of plants in their environment.
\end{abstract}

Keywords: Aby Lagoon, Wild edible plants, Ehotilé, Resources availability

\section{INTRODUCTION}

The quantity and quality of food available for consumption in West Africa are still well below the levels that could cover the nutrient recommendations by FAO / WHO (FAO/IFAD/UNICEF/WHP/WHO, 2019); however, populations in rural forest areas (those who still have harvesting activities) show only a few striking signs of malnutrition. The large amount of vitamins, proteins, fibres and other nutrients provided by gathered plants may explain this paradox (GautierBeguin, 1992). The balance of diets considered vulnerable to protein-related disorders is increasingly undermined, as dietary practices are in full mutations like other cultural aspects of the continent (Deslile, 2010; Aké Assi, 2014). Moreover, this situation is accelerated by the gradual degradation of the natural environment, causing the scarcity and remoteness of resources from potential users. The scarcity of these resources is a reason to fear the virtual disappearance of the knowledge and practices related to them since the usual value of a plant is strongly correlated with its availability (Lucena et al., 2007; Ribeiro et al., 2014). Moreover, as recalled by Lugo-Morin (2020), each social group and its territory have configured their own food systems, which have been refined since ancient times. Therefore, this study is set within the important framework of the imperative need to safeguard traditional knowledge at historical, and nutritional levels, and, above all, as an element of valorisation and sustainable management of natural resources. 
At the historical level, this study is necessary because the collective memory of the Ivorian Akan people, in general, does not go beyond the periods of exodus and present settlement, that is to say, towards the $17^{\text {th }}$ and $18^{\text {th }}$ centuries. However, the main food crops grown in the forest area, with the exception of African yams, are paradoxically native to other continents. What did these peoples eat before the introduction of these species? We believe, with Gautier-Beguin (1992) that the study of the "old and persistent" tradition of gathering, allows knowing what people ate before the development of the current food crops.

At the nutritional level, the destruction of the forest due mainly to the development of cash crops has led, often irreversibly, to strong erosion of traditional diet practices. These practices were one of the foundations of the social well-being of the communities. Current diets based on starchy foods (yams, cassava, rice, etc.) are far from meeting nutrient requirements (Bricas et al., 2016).

Moreover, the increasing interest in wild edible plants comes from growing demand for new resources for a healthy diet and new markers of cultural identity (Nedelcheva, 2013; Shin et al., 2018). Unfortunately, most of them are not well documented (Boateng et al., 2007). So, it is essential, as pointed out by Wondimu et al. (2006) and Aké Assi (2014) to rehabilitate and revalorise these practices for those who use them and to other peoples, as the main way for safeguarding this knowledge and the plants concerned. It is known that each plant that disappears also brings with it the disappearance of the knowledge that is related to it.

In southern Côte d'Ivoire, the riparian region of the Aby lagoon is one of the most degraded natural habitats. The few vegetations that have survived coconut palm, oil palm and rubber tree crops - are the marshy areas and islands of the Ehotilé Islands National Park (Malan et al., 2007). In the complex ethnic mix that characterizes the bank of the Aby Lagoon (eastern littoral of Côte d'Ivoire), the Ehotilé people differ from other Akan people. The originality of these people is conferred by its territorial anteriority, its history and lifestyle closely linked to the Aby lagoon (Perrot, 2008). This people is one of the first whose life and manners were described by the European missionaries of the end of the $17^{\text {th }}$ century, in particular in the writings of the Loyer (1714). The writings of Loyer offer a tremendous opportunity to observe the evolution of ancient practices of gathering or consumption of plants.

Thus, this study was aimed to identify the edible wild plants used by the Ehotilé, to evaluate the traditional knowledge (use, preference and availability) related to these plants and to discuss the evolution of food practices since the observations of Loyer three centuries earlier.

\section{MATERIALS AND METHODS}

\section{Study area}

The Ehotilé community is composed of nine main villages around the Aby Lagoon. The survey was conducted in six villages, bordering the Ehotilé Islands $\mathrm{Na}$ tional Park: Etuessika, Melekoukro, Ngalwa, Assomlan (western bank) and, Etuoboué and Akounougbé for the eastern bank (Fig. 1).

The climate of this zone is an equatorial transition type, characterized by four successive seasons: the long rainy season from March to July; the short dry season in August; the small rainy season from September to November and the large less rainy season, from December to February. The annual average rainfalls range from 1,800 to $2,000 \mathrm{~mm}$ and the annual average temperature is $26.4{ }^{\circ} \mathrm{C}$ with a variation of $3^{\circ} \mathrm{C}$.

The relief of the region is monotonous in the whole with some small plateaus of low altitudes (40 to $60 \mathrm{~m}$ ) with irregular contours, separated by usually quite steep valleys. The soils in this area are generally hydromorphic on Quaternary or young marine sands, within some places, large accumulations of plant debris.

The vegetation of the study area belonged to the Guinean Littoral Area characterized by a mosaic of edaphic groups (mangroves, coastal thickets, forests). The original vegetation (Licania eleosperma (Mildbr.) Prance \& White and Drypetes aframensis Hutch. Sub-littoral forest) has been replaced by cultivated areas.

Fishing is the main activity of the Ehotile people and until very recently (second quarter of the $20^{\text {th }}$ century), they were exclusively fishermen (Perrot 2008). Fishing activity (individual or collective) is practised by men and women. Fishing activities are particularly intense during the long rainy season and fall significantly in the dry season.

Agriculture is the second activity in the study area. From the stage of home consumption with food crops (cassava, yam, banana, etc.), it has increased to the stage of cash crop with coconut, oil palm, pineapple and rubber.

\section{Survey methods}

The ethnobotanical survey was carried out during four expeditions in 2007, 2009, 2015 and 2019 following three steps. The first one consisted of a house-tohouse interview, in households chosen without criteria, in the surveyed villages, as these were not very extensive. This approach allowed us to make observations on the current diet, and to discuss the question of uncultivated plants whose consumption was known by the respondents. Edible plant referred to any vegetable, consumed whole or partly, raw, after cooking or other transformation, as human's food or 


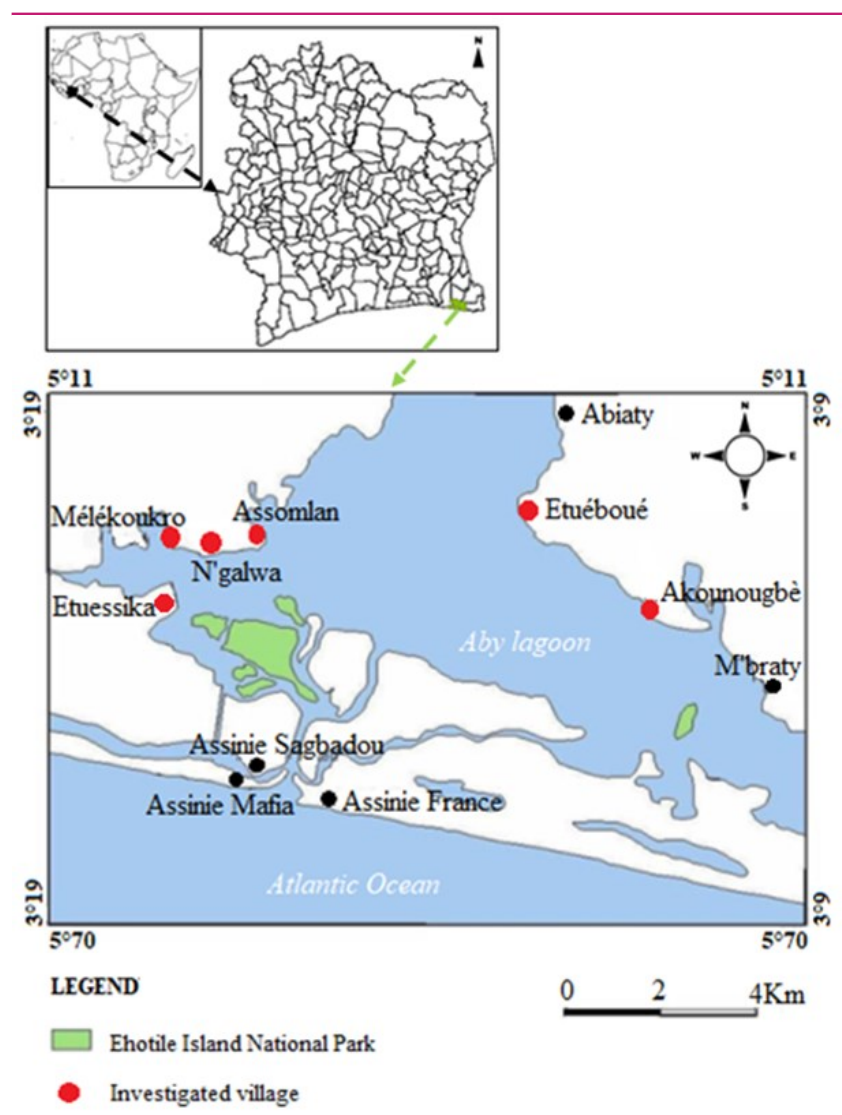

Fig. 1. Location of the study area, Ehotilé villages around the Aby lagoon.

drink. This definition included plants whose sap is directly drunk as water, irrespective of their medicinal nature. The notion of "wild" is restricted to species growing without intentional cultivation and included predominantly native and naturalised species. The most known plants and the order of preference were obtained through free listing interviews, as cited in Philips and Gentry (1993).

The second step consisted of a "walk-in-the-woods" approach in the neighbouring vegetation formations with key informants renowned for their good knowledge of plants and their uses. This method was allowed to establish a rigorous equivalence between ethnospecies and their scientific designation and to collect vouchers for a herbarium. The vouchers were identified at the Herbarium of Ivorian National Floristic Centre (ABJ) and the specimens were deposited at the Laboratory of Botany of Nangui Abrogoua University (Abidjan) and at the Institut de Botanique Aké Assi d'Andokoi (Abidjan). The last step was to come back to the most cited food category ("wild edible fruits" here) and to assess, with the informants, the availability of each plant cited according to a previously defined availability category (Malan et al., 2015).

At the end, 56 persons were interviewed (46 adults, including 26 women and 20 men aged 37-78 years and, 10 children aged $10-16$ years). The level of data saturation (point in data collection when no new information is added) and Informant competence (respondent-by-respondent proximity matrix) were checked with FLAME 1.1 (Pennec et al. 2012).

\section{Data analysis}

\section{Knowledge assessment}

The level of knowledge was assessed using Smith's index (Smith and Borgati, 1997; Sutrop, 2001), a cognitive salience index based on the rank of the item in the free list of each informant, its frequency in all collected free lists, and the individual length of the informant's list (Sutrop 2001). Smith index is given by the following equation:

$$
S a=\frac{\sum_{i=1}^{N} \frac{L i-R a+1}{L i}}{N}
$$

where $\mathrm{Sa}$ is the importance of item $a, L i$ the length of a list of citations and $R a$ the rank of a citation in the list and $N$, the total number of respondents (number of lists). This index, normed to vary between 1 (maximum importance) and 0, was also performed by FLAME 1.1 and the average rank was used to assess the preference of edible wild fruits of Ehotilé people.

\section{Evaluation of the availability of wild edible fruits}

It is known that local people followed the dynamics of the surrounding vegetation and they knew the common plant species in their region, those that were abundant or those that were in scarcity (Sheil et al., 2004). Based on this principle, the availability of wild edible fruits was estimated quantitatively according to the perception of informants. So, an availability index was proposed, adapted from the Cultural Importance index of Pardode-Santanya (2008). This new index consisted of allocating scores to plants according to their availability status given by the informant. Subjective allocation methods are widely used in quantitative ethnobotany (Hoffman and Gallaher, 2007; Medeiros et al., 2011). They typically consisted in assigning scores to distinguish, for example, acuity of use, conservation efforts, and other notions related to the perception of the plant by the considered community. Thus, in our case, a high score was attributed to the least available plants, since they require special attention in terms of conservation. Four categories of availability were identified (see Malan et al. 2015) with the following scores:

$\mathrm{C}_{1}=0.25$ : The plant abounds and the fruits are easy to collect or available in any season,

$\mathrm{C}_{2}=0.5$ : The plant abounds, but the fruits are difficult to harvest or available seasonally

$\mathrm{C}_{3}=0.75$ : The plant is becoming scarce in the region, only a few scattered feet are seen and the fruits are rare. 
$\mathrm{C}_{4}=1$ : The plant is in the process of disappearing, in the region, in the natural state, the fruits have only been seen for a long time.

The following equation was proposed:

$$
D i s_{i}=1-\frac{\sum_{j=1}^{4} n_{j} C_{j}}{N_{i}}
$$

Where Dis $s_{i}$ is the availability of the species $i, N_{i}$ the total number of informants who cited the species $i, n_{j}$ the number of respondents considering species $i$ in availability category $j, C_{j}$ the score assigned to availability category $j$. $D i s_{i}$ ranges from 0 to 1 . A value close to 0 indicated that the resource was disappearing on the local scale and that its use was becoming obsolete.

\section{Ethical considerations}

Prior to the fieldwork, the residents of each surveyed village were informed of the research project and prior consent was required in accordance with the recommendations of the Ethnobiology International Ethics Code for this research as well as the images used. These preliminary meetings took place in the court of the chief of the village and the conclusions were sealed, each time by a libation according to the Ehotilé customary protocol.

\section{RESULTS AND DISCUSSION}

\section{Observations on the diet of Ehotilé people}

The Ehotile diet was essentially based on cassava (Manihot esculenta Crantz), consumed in several forms. Apart from the akondin (plantains and cassava mixed and pounded), prepared dishes made from cassava, especially akpesi (cassava tubers cooked with water), were usually made for breakfast or lunch. Akondin, accompanied by soup, was the daily dinner for most households. The main accompanying soup was the nkwane prepared with eggplant (Solanum spp.) as main vegetables. The ayue-toro soup, prepared with oil palm (Elaeis guineensis Jacq.) fruit pulp, came in second place. Housewives preferred the wild palm nuts to those of the selected cultivated varieties, which would give a bland taste to the soup. Wild plant species were rarely used in the daily diet of Ehotilé, even, wild edible fruits, for example, have been known since the ancient time, as claimed by $80 \%$ of the respondents. Some informants, among the oldest, even cited the example of Sacoglottis gabonensis (Baill.) Urb. fruits which would constitute, in addition to the fish, the main menu of the Ehotilé.

\section{Wild edible plants used by Ehotilé people}

A total of 56 lists were obtained, with data saturation from the $5^{\text {th }}$ respondent (Fig. 2). Thirty-nine wild edible ethnospecies corresponding to 40 scientific plants species were recorded (the esthnospecies "elewa" corresponded to the two species of Uapaca recorded). Those species were distributed among 34 genera belonging to 24 families of Angiosperms (Table 1). Annonaceae (five species), Phyllanthaceae (four species), Arecaceae (four species) and Malvaceae (three species) were, numerically, the most important families. The length of free lists ranged from five to 15 with an average of 10.78 plants per list. These values indicated that wild edible species were well known by Ehotilé, which was confirmed by the high proximity of items cited given by the Respondent Competence Graph (Fig. 3). For these species, 46 uses were reported and classified in nine food-categories (Table 2). The most important category was by far, the "wild fruits" with $54.17 \%$ of uses-reports.

\section{Knowledge and preferences for wild edible fruits}

Out of 40 edible plants recorded, 23 were sought for the fruits. The level of consideration and preference of those wild fruits among Ehotilé people was estimated through the Smith's index (Fig. 4). Four fruits recorded a high salience (Smith'S>0.5). These included Sacoglottis gabonensis $(S=0.85)$, Parinari excelsa Sabine $(S=0.84)$, Dacryodes klaineana (Pierre) H.J.Lam $(\mathrm{S}=0.81) \quad$ (Fig. 5) and Cola lateritia var. maclaudi (A.Chev.) Brenan \& Keay (Figure 6) with $S=0.69$. These four species were also, in the same order, the most preferred following the average rank of the free lists. Indeed, none of them crossed the threshold of the fourth rank in the order of citations.

\section{Availability of wild edible fruits according to informants}

According to our informants and our own observations, edible wild fruits are available all year round, but irregularly (Table 3 ). Some fruits, like from Albertisia cordifolia (Mangenot \& Miège) Forman, Landolphia hirsuta (Hua) Pichon, Parinari excelsa, are only available for a short period of the year (less than 3 months for example), while some may be found at all times (Carpolobia lutea G.Don, Heisteria parvifolia Sm., Passiflora foetida L., Uapaca esculenta A.Chev. ex Aubrév. \& Léandri and $U$. paludosa Aubrév. \& Léandri, for example). Paradoxically, the most available fruits are the least considered. Mature fruits of Heisteria parvifolia for example, available throughout the year, collected only an index of Smith of 0.16 (average rank of 8.96). Moreover, in the local language, this species is called "komu alie" which means "food of the apes". 


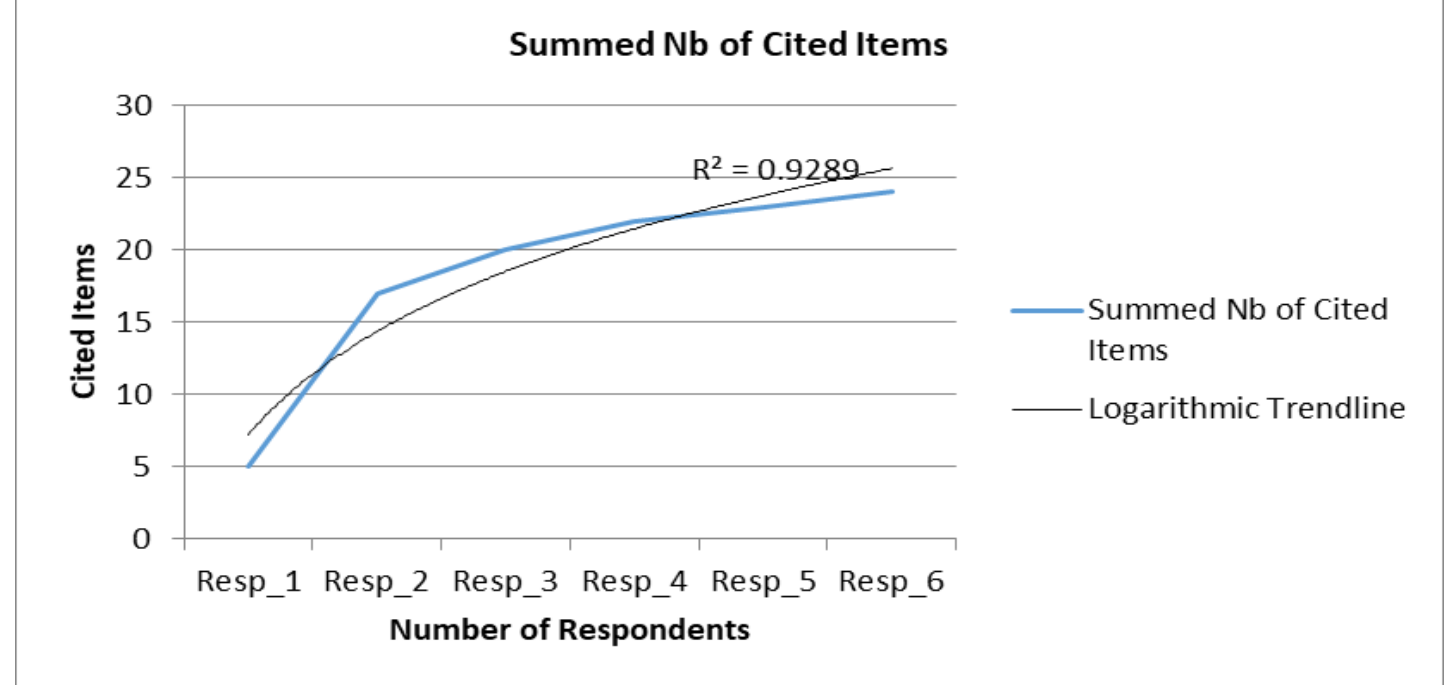

Fig. 2. Level of data saturation of wild edible plants cited by Ehotilé people.

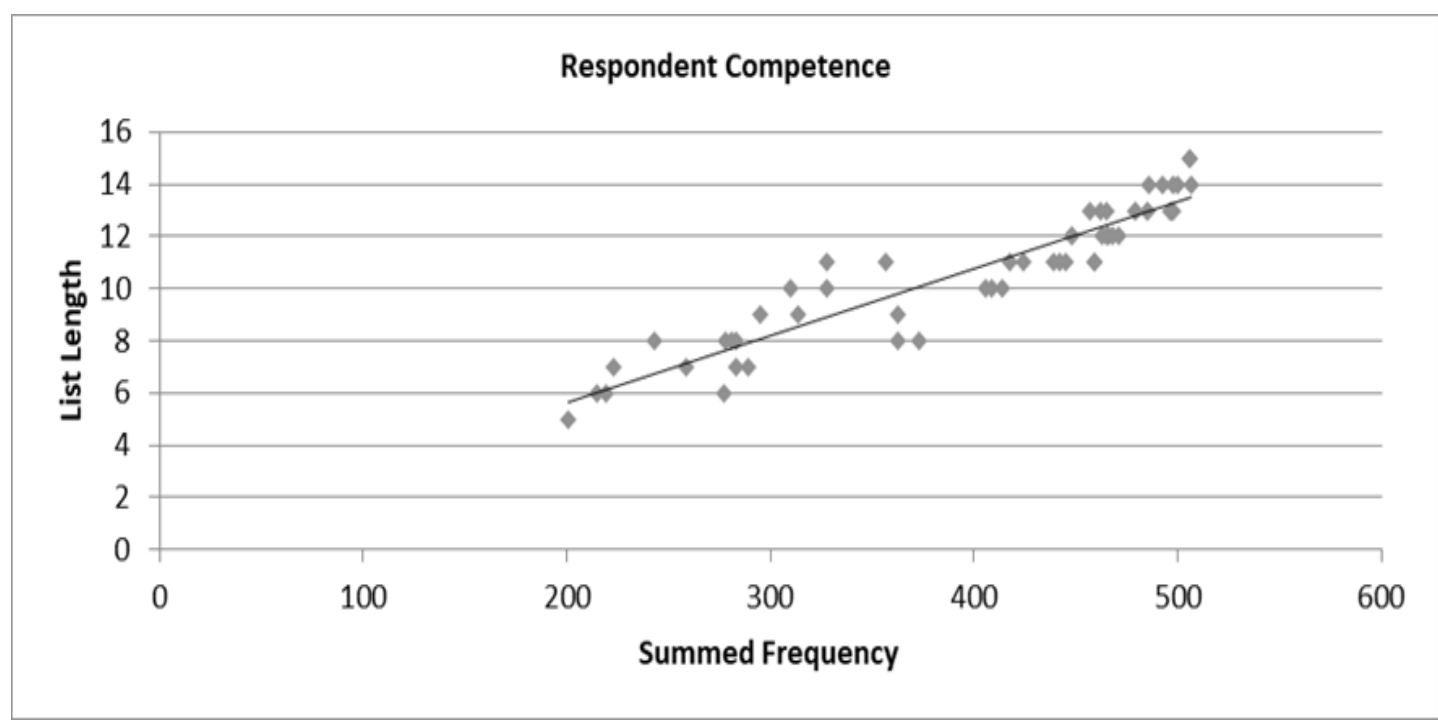

Fig. 3. Ehotilé Informant competence in wild edible plants.

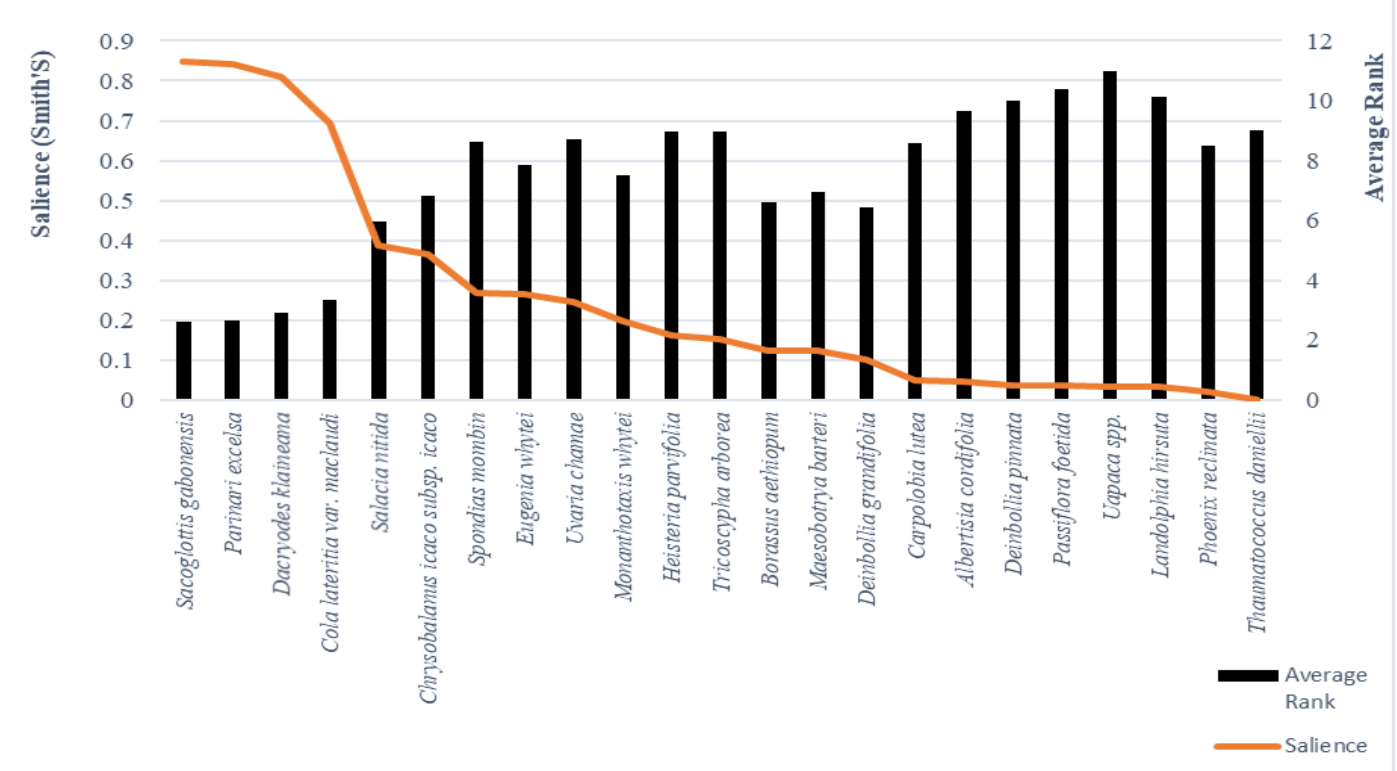

Fig. 4. Salience and preference of wild edible fruits by Ehotilé community. 
Malan, D.F. and Neuba, D.F.R / J. Appl. \& Nat. Sci. 13(1): 59 - 70 (2021)

Table 1. List of wild edible plants of Ehotilé people.

\begin{tabular}{|c|c|c|c|}
\hline Species & Family & Local name & $\begin{array}{l}\text { Organ and } \\
\text { consumption mode }\end{array}$ \\
\hline Adenia lobata (Jacq.) Engl. & Passifloraceae & Ahèlè nyaman & Sap drunk like water \\
\hline $\begin{array}{l}\text { Albertisia cordifolia (Mangenot \& Miège) } \\
\text { Forman }\end{array}$ & Menispermaceae & Kinninglin gni & Pulp as a snack \\
\hline & & & $\begin{array}{l}\text { Pulp as a snack, } \\
\text { leaves as spinach, }\end{array}$ \\
\hline Borassus aethiopum Mart. & Arecacae & Kube & $\begin{array}{l}\text { Fresh or cooked pulp, } \\
\text { fresh almond, sap } \\
\text { fermented for drink }\end{array}$ \\
\hline Carpolobia lutea G.Don & Polygalaceae & Sekenua & Pulp as a snack \\
\hline Chrysobalanus ellipticus Soland. ex Sabine & Chrysobalanaceae & Acho & Pulp as a snack \\
\hline $\begin{array}{l}\text { Cola lateritia var. maclaudi (A.Chev.) Brenan \& } \\
\text { Keay }\end{array}$ & Sterculiaceae & Dabu dabu & Pulp as a snack \\
\hline Cola nitida (Vent.) Schott \& Endl. & Sterculiaceae & Ewosè & $\begin{array}{l}\text { Seed eaten as a } \\
\text { stimulant }\end{array}$ \\
\hline Corchorus olitorius L. & Malvaceae & Kpalala & Pulp as a snack \\
\hline Dacryodes klaineana (Pierre) H.J.Lam & Burseraceae & Klènja & Pulp as a snack \\
\hline Deinbollia grandifolia Baker.f. & Sapindaceae & Nzema klènja & Pulp as a snack \\
\hline Deinbollia pinnata (Poir.) Schumach. \& Thonn. & Sapindaceae & Ekpokolobo & Pulp as a snack \\
\hline Elaeis guineensis Jacq. & Arecaceae & Ayue & $\begin{array}{l}\text { pulp cooked as sauce, } \\
\text { fresh almond, sap } \\
\text { fermented for drink }\end{array}$ \\
\hline Eugenia whytei Sprague & Myrtaceae & Ehube & Pulp as a snack \\
\hline Heisteria parvifolia Sm. & Olacaceae & komu aliè & Pulp as a snack \\
\hline Landolphia hirsuta (Hua) Pichon & Apocynaceae & Amanlè & Pulp as a snack \\
\hline $\begin{array}{l}\text { Maesobotrya barteri (Baill.) Hutch. var. } \\
\text { sparsiflora (Scott-Elliot) Keay }\end{array}$ & Euphorbiaceae & Anuven & Pulp as a snack \\
\hline Monanthotaxis whytei (Stapf) Verdc. & Annonaceae & Matman ngangan sa & Pulp as a snack \\
\hline Monodora myristica (Gaertn.) Dunal & Annonaceae & Efuan & seed as condiment \\
\hline Musanga cecropioides R.Br. & Cecropiaceae & Ejugn & Sap drunk like water \\
\hline Myrianthus arboreus P.Beauv. & Cecropiaceae & Nyangoman & $\begin{array}{l}\text { Pulp as a snack, } \\
\text { leaves as spinach }\end{array}$ \\
\hline Ocimum gratissimum $\mathrm{L}$. & Lamiaceae & Amanyine & $\begin{array}{l}\text { Leaves eaten as } \\
\text { spinach }\end{array}$ \\
\hline Parinari excelsa Sabine & Chrysobalanaceae & Efalan & Pulp as a snack \\
\hline Passiflora foetida L. & Passifloraceae & Ewo aliè & Pulp as a snack \\
\hline Phoenix reclinata Jacq. & Arecaceae & Ngletia & Pulp as a snack \\
\hline Phyllanthus muellerianus (Kuntze) Exell & Euphorbiaceae & Ngoninjin & Sap drunk like water \\
\hline Raphia hookeri Mann ex Wendl. & Arecaceae & Doka & $\begin{array}{l}\text { Sap fermented for } \\
\text { drink }\end{array}$ \\
\hline Ricinodendron heudelotii (Baill.) Pierre ex Pax & Euphorbiaceae & Akpi & Seed cooked in sauce \\
\hline Sacoglottis gabonensis (Baill.) Urb. & Humiriaceae & Afandè & Pulp as a snack \\
\hline Salacia nitida (Benth.) N.E.Br. & Celastraceae & Boa ndoman & Pulp as a snack \\
\hline Solanum nigrum L. & Solanaceae & Fue nya & Pulp as a snack \\
\hline Spondias mombin L. & Anacardiaceae & Troman & Pulp as a snack \\
\hline Talinum triangulare (Jacq.) Willd. & Portulacaceae & Dahome nya & Pulp as a snack \\
\hline Tetracera alnifolia Willd. & Dilleniaceae & Ngataku & Sap drunk like water \\
\hline Thaumatococcus daniellii (Benn.) Benth. & Marantaceae & Ewosè nya & Pulp as a snack \\
\hline Trichoscypha arborea (A.Chev.) A.Chev. & Anacardiaceae & Amon & Pulp as a snack \\
\hline Uapaca esculenta A.Chev. ex Aubrév. & Euphorbiaceae & Elèwa & Pulp as a snack \\
\hline Uapaca paludosa Aubrév. \& Léandri & Euphorbiaceae & Elèwa & Pulp as a snack \\
\hline Uvaria afzelii Scott-Elliot & Annonaceae & Lokofama, kusini & Pulp as a snack \\
\hline Uvaria chamae P.Beauv. & Annonaceae & Matman sa & Pulp as a snack \\
\hline Vernonia amygdalina Delile & Asteraceae & Aboyui & Pulp as a snack \\
\hline Xylopia aethiopica (Dunal) A.Rich. & Annonaceae & Esin & $\begin{array}{l}\text { Dried fruits as a } \\
\text { condiment }\end{array}$ \\
\hline
\end{tabular}


Table 2. Food-categories and their uses reports of wild edible plants of Ehotilé people.

\begin{tabular}{lll}
\hline Food-category & Number of uses- & Proportion \\
\hline Wild fruits & 24 & 52,2 \\
Vegetable & 5 & 10,9 \\
Drinking water & 4 & 8,7 \\
Palm wine & 4 & 8,7 \\
Condiment & 3 & 6,5 \\
spices & 2 & 4,3 \\
Soup & 2 & 4,3 \\
fresh seeds & 1 & 2,2 \\
Stimulant & 1 & 2,2 \\
Oil & 46 & 100 \\
\hline Total & & \\
\hline
\end{tabular}

Table 3 shows the availability of fruit plants according to the informants. Ten of the 23 fruit species have an availability index less than or equal to 0.5 , indicating that these species or the fruits sought were rare in the region. Of these species, three were cited in category $\mathrm{C} 4$, i.e. disappearing plants, in the region and for which fruits had only been seen for a long time. These scarce species included Trichoscypha arborea (A.Chev.) A.Chev (Dis=0.009), Phoenix reclinata Jacq (Dis= $0.124)$ and Dacryodes klaineana (Dis=0.263). The Pearson's Correlation Index (-0.06) showed that there was no correlation between knowledge (brought by Smith's index) and availability (brought by availability index).

\section{DISCUSSION}

The history of the food of a region or a population necessarily starts from the resources, which compose the dishes, of which the cultivated plants represent the

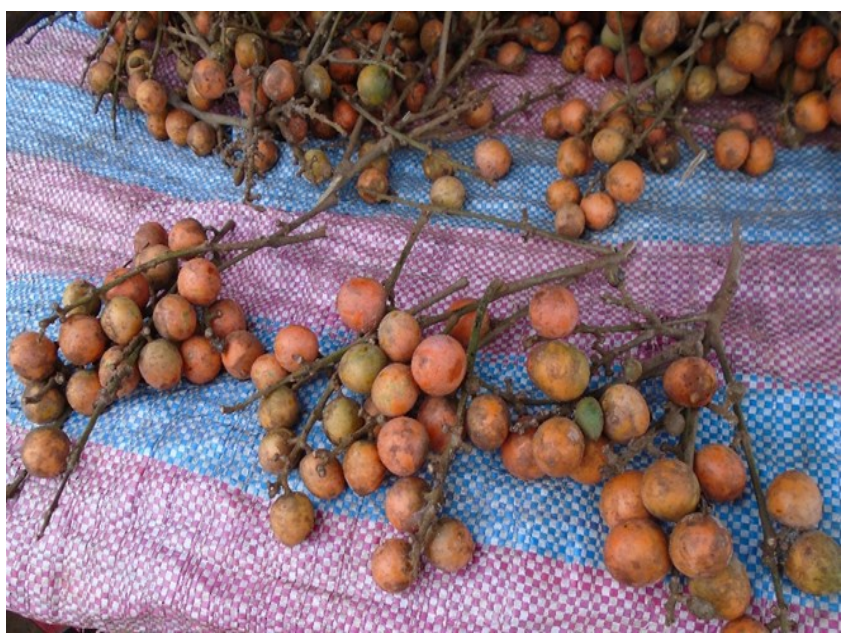

Fig 5. Bunches of Dacryodes klaineana (Pierre) H.J.Lam fruits, one the most considered and preferred edible fruits of Ehotilé people sold on a local market (Photo by Malan D.F. 03-01-2019). basic ingredients (Juhé-Beaulaton, 2014a). The missionary accounts, the most important of which, in our opinion, were those of the apostolic prefect, Godfroy de Loyer, who observed in depth the life of the people of the Kingdom of Issyny between 1701 and 1703, described an agrarian landscape and dishes, very different from what this region offers today. The current Ehotilé diet, as we have observed, is based on cassava. However, the writings of Loyer and contemporaries mentioned neither the culture nor the consumption of cassava in the Kingdom of Issyny. On the contrary, these accounts showed that in three centuries, the diet of the Ehotile has greatly changed. The "starchy and soup" frame were preserved, but the nature of the basic starchy food has undergone a revolution. Indeed, according to Loyer, the basic starchy foods were banana, yam, rice, maize and millet. With the cereals, "bread" was made, which with soup, was the main dish. The cultivation and consumption in large quantities of cassava, a witness of cultural enrichment, is relatively recent. As we know, cassava was introduced at a number of points along the West African coast during the $17^{\text {th }}$ century, from the Gambia River to present-day Nigeria. The Portuguese had established their forts, trading posts and colonies on the mainland, and by the end of the $17^{\text {th }}$ century, cassava was present in most of these places (Carter et al., 1994).

Unlike central Africa, the spread of cassava in West Africa was generally slow, and the expansion of the crop took place largely in the late $19^{\text {th }}$ and $20^{\text {th }}$ centuries. In Côte d'Ivoire, cassava cultivation did not really take off until 1960 (Diarrassouba, 2019). Its adoption set back the cultivation of other essential plants in the area, which, moreover, did not develop well on a soil that was gradually degraded due to the expansion of cash crops (coconut and oil palm, in

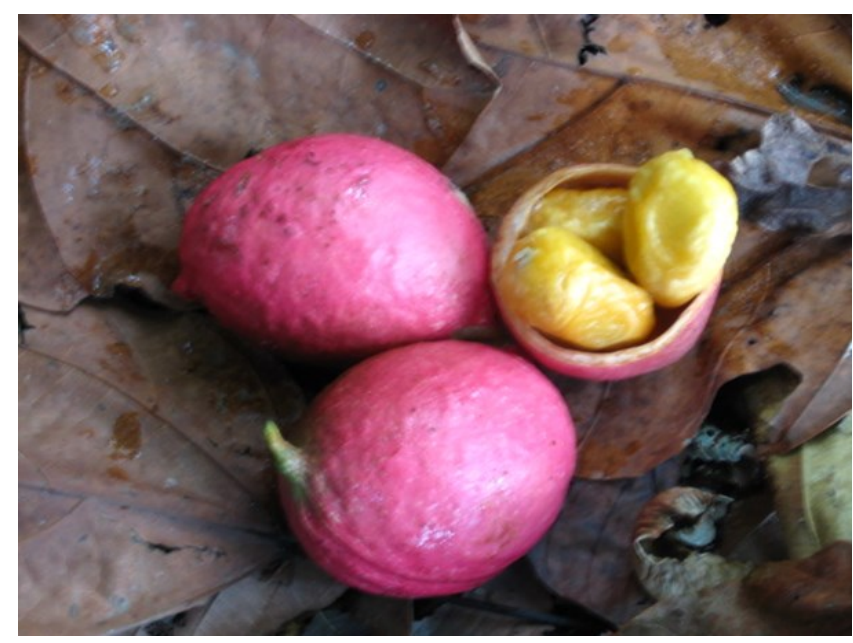

Fig. 6. Fruits of Cola lateritia var. maclaudii, one the most considered and preferred edible fruits of Ehotilé people (Photo Malan D.F. 12-03-2015). 


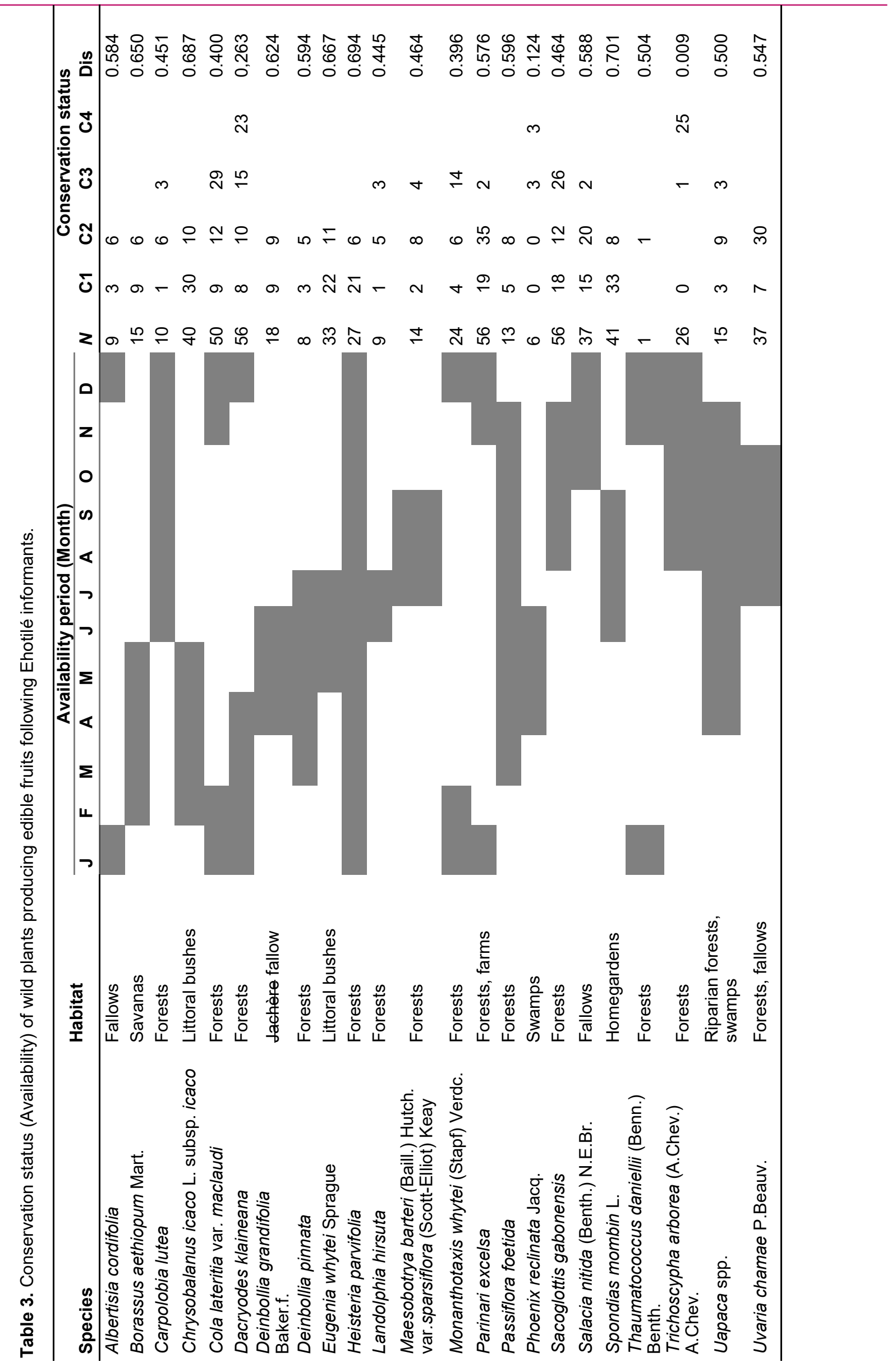


particular).

Like the starchy food, the second component of the menus, the soup, has also experienced a revolution. According to Loyer, the main soup was palm nut soup. Admittedly, this soup is still used today, but the main soup for Ehotilé households is mainly made from eggplants (nkwane soup). In our opinion, two reasons might explain this change. Firstly, the scarcity of natural palm trees (paradoxically due to the development of the cultivation of so-called improved varieties of palm). This scarcity implies an increase in the time and effort required to find natural fruits. Secondly, the preparation of nkwane requires relatively less time and effort in cooking, contrary to the first soup. As we know, the effort of exploitation is one of the main factors of abandonment of plant use, especially when, at the same time, a resource appears, easier to exploit and quickly accessible.

Regarding wild edible plants, we observed a low use of leaves and seeds in favour of fruits and a total absence of tubers. The low use of the leaves was due to the diet strongly focused on two almost exclusive soups (nkwane and ayue-toro). These soups are preferred to those based on leaves, borrowed from other cultures. For example, the consumption of the leaves of Talinum triangulare and Vernonia amygdalina was borrowed from Togolese and Beninese (Dahomean) immigrants. $T$. triangulare was called, in the local language, dahome nya (leaves of the Dahomeans). This low proportion of leaves in Ehotilé food practices was in contrast to the general case of West African peoples, where leaves constitute a highly sought-after organ for human consumption (Acho et al., 2014; Yao et al., 2015). On this point, the current Ehotilé are in no way different from their ancestors who lived in the wake of Issyny. Loyer was surprised, in fact, by the low diversity of meals, which contrasted with the high diversity of potentially edible plant resources. According to him, this situation was due to the "laziness and lack of ingenuity" of the people he observed.

As regards seeds, their proportion in the consumption of picking products is lower than that of leaves. Even the seeds of African nut tree (Ricinodendron heudelotii (Baill.) Pierre ex Pax), known as an important source of lipids and widely consumed in West and Central Africa (Tchoundjeu and Atangana, 2007) were rarely consumed by the Ehotilé.

Our survey reported the use of the sap of certain plants drunk as water or as a fermented beverage. In the first case, the plants collected (Adenia lobata (Jacq.) Engl., Phyllanthus muellerianus (Kuntze) Exell and Musanga cecropioides R.Br.) are widely known in forest Africa for the same use (Tra bi et al., 2005; Jongkind and Hawthorne, 2005). In the second case, Borassus aethiopum Mart., Elaeis guineensis and Raphia hookeri Mann ex Wendl. produce a fermented drink known as palm wine. It is an important cultural element in Western and Central Africa and contributes to the balance of the diet, by its richness in nutrients, as shown by several authors (Ezeagu et al., 2003; Santiago-Urbina and Ruiz-Teran, 2014; Kouchade et al., 2017; Djeni et al., 2020). Currently, palm wine is obtained mainly from oil palm and Raphia palm. However, according to the old accounts of Loyer and other explorers such as Labat (1728), only the Raphia palm was exploited for its wine. The oil palm was reserved for its fruit. However, currently, the rarefaction of Raphia, the development of industrial palm have imposed oil palm wine among the Ehotilé.

Fruits constitute the major part of the plant organs sought by the Ehotile (61\%). They were sought after for their tasty pulp, sweet and rich aromas. Children, often at the foot of the tree, mostly eat them as treats. The importance of wild edible fruits in the food security of rural populations is no longer to be demonstrated, as there is so much work in this area ( Chakravarty et al., 2016; Sardeshpande and Shackleton, 2019). These fruits were well known to the population as evidenced by the average length of the free lists and the data saturation graph. However, they were rarely present in local markets, contrary to what is observed elsewhere (Djihounouck et al. 2018; Sardeshpande and Shackleton, 2019).

This finding may be related to the availability of productive plants. The evaluation of the availability of wild edible plants was one of the major points of this study. Several researchers have used ecological field methods for this evaluation, such as the rarity index of Géhu and Géhu (1980) based on sampling in the immediate environment of ethnobotanical surveys. Certainly, diversity indices are useful tools that help us to ask questions and analyze ethnobotanical data, besides allowing comparisons among different communities in different or similar environments (Begossi, 1996). However, these kinds of surveys take time and the results are only a reflection of often random or arbitrary sampling. With de la Torre et al. (2012), Roué et al. (2015), we believe that local people are at the heart of the environment interactions, problems and solutions to be found. Thus, a cognitive approach, centred on the sought organ than on the plant that produces the resource, targets more scarce resources at the local level. Indeed, as several researchers have noted, plant resources are sustained through cultural practices where plant users collect and harvest materials selectively using locally adapted management strategies (Rasethe et al., 2013; Constant and Tshisikhawe, 2018; Thorn et al., 2020). The survey on the availability of resources based on the respondent's knowledge suggested that $43.5 \%$ of wild edible fruits were in scarcity in the study area. However, as noted by Koppert et al. (1996), to have a significant influence on food, wild products should be 
collected very regularly, which implies their abundance in very specific territories and not far from places of activity or residence. More worryingly, the species Trichoscypha arborea (96\% of those who cited it), Phoenix reclinata (50\% of those who cited it) and Dacryodes klaineana (41\%) were considered to be endangered, in the region, in their natural habitat, the organs sought after having only been seen for a long time. The disappearance of these species was mainly linked to the scarcity of their natural habitats in the region because of extensive agriculture. The local name of $T$. arborea is even unknown to young people and children.

It is, therefore, to be feared, in the current state, a progressive reduction in the proportion of wild plants in the diet of the Ehotilé. It is a process which unfortunately seems irreversible in the light of the accounts of Loyer and contemporaries. Two examples can illustrate the decline of wild edible plants in the diet of the Ehotilé. The first is given by Guinea pepper (Xylopia aethiopica (Dunal) A.Rich.). In the days of the Kingdom of Issyny, according to Loyer's observations, this pepper was the main spice in the soups of the inhabitants who, he wrote, loved it "with passion". Today, with the exception of certain meals for therapeutic purposes, such as those prepared for newly delivered women, Guinea pepper is no longer used as a condiment. It has given way to chili (Capsicum frutescens L.), introduced from America, widely cultivated and adopted by households.

The second example is that of Synsepalum dulcificum (Schumach. \& Thonn.) Daniell known for its red berries, which contain miraculin, a glycoprotein. Miraculin has the remarkable property of modifying sour tastes into sweet, as Loyer testified: "There grows in this kingdom a certain little fruit which they call Assahuaye, as big as a mediocre plum, red in colour, which is no bigger only the finger: they have almost only the skin. So that sucking them there is only a sweetish and tasteless taste. But these fruits have such a quality, that after having sucked only one, you can fearlessly eat the greenest and sourest lemons and oranges, and drink the harshest vinegar, which appears to taste very delicate jams and very excellent syrup, which I have experienced several times with admiration, so great is the strength of this alkali fruit, which undoubtedly would have wonderful properties in medicine". As noted by Juhé-Beaulaton (2014b), this species is now cultivated outside Africa, in Asia and America. Paradoxically, on the coast of the Gulf of Guinea, where it was present particularly near homes, it seems rarer and less used in food while the consumption of sugar has greatly increased. Certainly, the decline in consumption of wild plants is a consequence of the introduction in the middle of the $17^{\text {th }}$ century of new plant species including rice, potatoes, tomatoes, pepper, maize (Nedelcheva, 2013).

In contrast to these two examples, there is at least one fruit consumed today and that was in the days of Issyny. This is cocoplum (Chrysobalanus icaco L. subsp. icaco). As Loyer described it, "it is a kind of plum in the shape and colour of which a European would doubtless be deceived, but which have only the skin extended on a large mediocre hard nucleus which contains a fairly good almond when it is cooked but a little harsh on the palate, when it is raw. The countryside is covered with it and there are all the colours. The tree which carries them commonly crawls on the ground, although there are some in the full wind which becomes reasonably large".

Nowadays, this fruit is relatively abundant (Dis $=0.69$ ) according to the informants, and it is indeed clearly visible in the coastal bushes. However, it is only moderately known $(S=0.37$ ) and comes in the sixth position in the order of preference for fruits, with an average rank of 6.82 . Furthermore, the consumption of roasted kernels noted by Loyer was not mentioned during our study, which indicates gradual obsolescence in the consumption of this plant.

Regarding our new cognitive method of evaluating the availability of resources based on the knowledge of those who use them, it is based on a solid principle: those who have always lived in the environment where the resources they use to grow to know better the dynamics of these resources. Thus, for example, plants considered to be rare were not actually seen during our various visits. However, to further consolidate this method, a comparison with a field survey method using indices of occurrence (frequency of occurrence, density or frequency of rarefaction, etc.) is necessary. Such an approach is in prospect.

\section{Conclusion}

The findings of this study showed that in three hundred years, the diet of Ehotilé had changed significantly only in the composition of the basic meal. Unlike the precolonial era, cassava, which recently appeared in this region, has become the starchy staple in a few years. However, with regard to gathered edible plants, just like in the pre-colonial era, they constitute only a small part of the Ehotilé diet, despite their knowledge. Leafy vegetables and seeds were less used in favour of fruits. While the fruits are well known, however, their low presence in local markets is a good indicator of their gradual abandonment. This low consumption, correlated with the progressive scarcity of several plants revealed by our availability index based on respondents' knowledge, could raise fears of several wild edible 
plants disuse, as is the case today for guinea pepper (Xylopia aethiopica). Thus, we agreed that the history of the use of wild plants as food is in fact part of the history of the people in this area, an inevitable result of the dynamic processes of the structure of the society, the cultural relationships and the religious characteristics and changes in the environment. Moreover, this study also confirmed that local people have a good knowledge of the fluctuation in the availability of edible wild plants and could therefore be key resource persons in any assessment of the dynamics of plants in their environment..

\section{ACKNOWLEDGEMENTS}

We extend our warm thanks to the populations of the Ehotile villages of the Aby lagoon, for their great hospitality. Thanks also to Kouamé Marcelin for proofreading, Kougbo Distel for improving the mapping and Kouamé Benoit for revising the formula of our cognitive availability equation.

\section{Conflict of interest}

The authors declare that they have no conflict of interest.

\section{REFERENCES}

1. Acho, C.F., Zoué, L.T., Akpa, E.E., Yapo, V.G. \& Niamké, S.L. (2014). Leafy vegetables consumed in Southern Côte d'Ivoire: a source of high value nutrients. J Anim Plant Sci., 20, 3159-3170.

2. Aké-Assi, L. (2014). Some food plants from West Africa. Their safeguard and their enhancement. NEI-CEDA, Abidjan.

3. Begossi, A. (1996). Use of ecological methods diversity indices. Econ Bot., 50, 280-289.

4. Boateng, S.K, Adu Yeboah, E. \& Amponsah, J.Y. (2007) Wet season collection of edible wild fruits in three regions of Ghana. J Plant Sci., 2, 353-357. https://doi.org/10.3923/ jps.2007.353.357

5. Bricas, N., Tchamda. C. \& Martin, P. (2016). Food consumption structures In: Bricas, N., Tchamda, C, Mouton F. (eds) Africa to conquer its food market. Teaching of ten years of household surveys in west Africa, Cameroun and Tchad. Paris AFD, collection « Études de l'AFD »12, 132

6. Carter, S.E, Fresco, I.O., Jones, P.G. \& Fairbairn, J.N. (1994). Introduction and dissemination of cassava Africa. Research Guideline IITA, 49.

7. Chakravarty, S., Bhutia, K.D., Suresh, C.P., Shukla, G. \& Pala, N.A. (2016). A review on diversity, conservation and nutrition of wild edible fruits. Journal of Applied and Natural Science, 8: 2346-2353. https://doi.org/10.31018/ jans.v8i4.1135

8. Constant, N.L. \& Tshisikhawe, M.P. (2018). Hierarchies of knowledge: ethnobotanical knowledge, practices and beliefs of the Vhavenda in South Africa for biodiversity conservation. J Ethnobiol. Ethnomed., 14, 56. https://
doi.org/10.1186/s13002-018-0255-2Diarrassouba, D. (2019). History and techniques of food crops in the Côte d'Ivoire, from processing to marketing : the cas of cassava (1960-2000) », e-Phaïstos [On line], consulted on 28 April 2020. URL : http://journals.openedition.org/ephaistos/4174

9. Djeni, T.N., Kouamé, K.H., Aké, F.D.M., Amoikon, L.T., Djè, K.M. \& Jeyaram, K. (2020). Microbial diversity and metabolite profiles of palm wine produced from three different palm tree species in Côte d'lvoire. Sci Rep., 10,1715. https://doi.org/10.1038/S41598-020-58587-2

10. Djihounouck, Y., Diop, D., Dieng, S.D., Sane, S., Bassène, C., Mbaye, M.S. \& Noba, K. (2018). Diversity and socio-economic importance of wild edible fruit species in the area Kasa (South West of Sénégal). Eur Sci J., 14. https://doi.org/10.19044/esj.2018.v14n36p352

11. Delisle, H. (2010). Findings on dietary patterns in different groups of African origin undergoing nutrition transition. Appl Physiol Nutr Metab., 35, 224-228. https:// doi.org/10.1139/H10-008

12. Ezeagu, I.E., Fafunso M.A., Ejezie, F.E. (2003). Biochemical constituents of palm wine, Ecol Food Nutr 42 (3) :255264. https://doi.org/10.1080/03670240390226222

13. FAO, IFAD, UNICEF, WFP, WHO (2019). The State of Food Security and Nutrition in the World 2019. Safeguarding against economic slowdowns and downturns. Rome, FAO. Licence CC BY-NC-SA 3.0 IGO.

14. Medeiros, M.F.T., da Silva, P.S. \& de Albuquerque, U.P. (2011). Quantification in ethnobotanical research : an overview of indices used from 1995 to 2009. Sitientibus, Ciências Biológicas, 11(2), 211-230. https:// doi.org/10.13102/scb108

15. Gautier-Béguin, D. (1992). Gathering plants for food use in central Côte d'Ivoire. Boissiera. 46.

16. Géhu, J.M. \& Géhu, J. (1980). Objection test of the biological evolution of natural environments. Coastal examples. In Géhu, J.M. (ed). Applied Phytosociology wokshop. Amicale Francophone de Phytociologie, Metz. 28-29 March 1980

17. Hoffman, B. \& Gallaher, T. (2007). Importance Indices in Ethnobotany. Ethnobot. Res. Appl., 5, 201-218. https:// doi.org/10.17348/era.5.0.201-218

18. Jongkind, C.C.H. \& Hawthorne, W.D. (2005). A botanical synopsis of lianes and other forest climbers. In Forest Climbing Plants of West Africa. Diversity, Ecology and management. Bongers, F., Parren, M.P.E. \& Traoré, D. (Eds). CABI publishing, Wallingford, UK. : 19-40.

19. Juhé-Beaulaton, D. (2014a). From yam to cassava in the gulf of Guinea : slave trade and food in the the Danhomè kingdom (XVIle -XIXe siècle). Afriques [On line], consulted on 28 May, 2020. https://doi.org/10.4000/afriques.1669

20. Juhé-Beaulaton, D. (2014b). The miracle fruit (Synsepalum dulcificum) travelers on the West African coast to pharmaceutical laboratories. Open Archives [On line], https://halshs.archives-ouvertes.fr/halshs-01103549/ file/2014_Juhe_Fruit\%20miracle2, consulted on 12 May, 2020.

21. Koppert, G.J.A., Dounias, E., Froment, A. \& Pasquet, P. (1996). Food consumption in three forest population region of Cameroun : Yassa, Mvae et Bakola. In: tropical forest food, interactions and development perspectives. Volume I. Hladik CM, Hladik A, Pagezy H, Linares, O.F., 
Koppert, J.A. \& Froment, A. (Eds). MAB/UNESCO, Paris, France., 477-496.

22. Kouchade, C.A., Kounouhewa, B. \& Awokou, S.K. (2017). Harvesting palm wine: process and effects of environmental. OCL 2017, 24(5), D505. https://doi.org/10.1051/ ocl/2017035

23. Labat, J. B. (1728). Nouvelle relation de l'Afrique occidentale contenant une description exacte du Sénégal et des païs situés entre le Cap-Blanc et la rivière de Serrelienne jusqu'à plus de 300 lieues en avant dans les terres. https://gallica.bnf.fr/ark:/12148/bpt6k74103p?rk=21459;2

24. Loyer, G. (1714). Relations du voyage au Royaume d'Yssiny, Côte d'Or, Païs de Guinée, en Afrique http:// gallica.bnf.fr/ark:/12148/bpt6k86203n

25. Lucena, R.F.P., Lima, E. \& Albuquerque, U.P. (2007). Does the local availability of woody Caatinga plants (Northeastern Brazil) explain their use value? Econ Bot., 61(4), 347-61.

26. Lugo-Morin, D.R. (2020). Indigenous communities and their food systems: a contribution to the current debate. J Ethnic Foods. 7:6. https://doi.org/10.1186/s42779-019-0043-1

27. Malan, D.F., Aké Assi, L., Tra Bi, F.H. \& Neuba, D. (2007). Diversité floristique du parc national des îles Ehotilé (littoral est de la Côte d'Ivoire). BFT 292, 49-58. https:// doi.org/10.19182/bft2007.292.a20348

28. Malan, D.F., Neuba, D.F.R. \& Kouakou, K.L. (2015). Medicinal plants and traditional healing practices in Ehotilé people, around the aby lagoon (eastern littoral of Côte d'Ivoire). J Ethnobiol Ethnomed., 11, 21. https://doi.org/ 10.1186/s13002-015-0004-8

29. Nedelcheva, A. (2013). An ethnobotanical study of wild edible plants in Bulgaria. EurAsian J BioSci. 7, 77-94. https://doi.org/ 10.5053/ejobios.2013.7.0.10

30. Philips, O. \& Gentry, A. (1993). The useful woody plants of Tambopata, Peru: I. Statistical hypothesis tests with a new quantitative technique. Econ Bot., 47, 16. https:// doi.org/10.19182/bft2007.292.a2034810.1007/ BF02862203

31. Pennec, F., Wencélius, J., Garine, E., Raimond, C. \& Bohbot, H. (2012). FLAME 1.1 Free-List Analysis under Microsoft Excel.

32. Perrot, C.-H. (2008). The Eotilé of Côte d'Ivoire in the $18^{\text {th }}$ and $19^{\text {th }}$ centuries. Lineage power and religion. Sorbonne publications, Paris.

33. Rasethe, M.T., Semenya, S.S., Potgieter, M.J. \& Maroyi, A. (2013). The utilization and management of plant resources in rural areas of the Limpopo Province, South Africa. J Ethnobiol Ethnomed., 9, 27. https:// doi.org/10.1186/1746-4269-9-27
34. Ribeiro, J.P., Carvalho, T.K.N., Ribeiro, J.E., de Sousa, R.F., de Farias, L.J.R., de Oliveira, R.S., Alves, C.A.B., Jardim, J.G. \& de Lucena, R.F.P. (2014). Can ecological apparency explain the use of plant species in the semiarid depression of Northeastern Brazil? Acta Bot. Bras., 28(3), 476-483. https://doi.org/10.1590/0102-3306201 $4 a b b 2758$

35. Roué, M., Battesti, B., Césard, N. \& Simenel, R. (2015). Ethnoecology of pollination and pollinators, Revue d'ethnoécologie [Online], 7. URL : http://journals.openedit ion.org/ethnoecologie/2229 ; https://doi.org/ 10.4000/ ethnoecologie. 2229

36. Sardeshpande, M. \& Shackleton, C. (2019). Wild Edible Fruits: A Systematic Review of an Under-Researched Multifunctional NTFP. Forests, 10, 467; https:// doi.org/10.3390/f10060467

37. Santiago-Urbina, J. A. \& Ruíz-Terán, F. (2014). Microbiology and biochemistry of traditional palm wine produced around the world. Int. Food Res. J.. 21(4), 1261-1269

38. Shin, T., Fujikawa, K., Moe, A.Z.. \& Uchiyama, H. (2018). Traditional knowledge of wild edible plants with special emphasis on medicinal uses in Southern Shan State, Myanmar. J Ethnobiol. Ethnomed., 14:48. https:// doi.org/10.1186/s13002-018-0248-1

39. Smith, J.J. \& Borgatti, S.P. (1997). Salience counts-and so does accuracy: Correcting and updating a measure for free-list-item salience. J. Linguist. Anthropol., 7: 208-209. https://doi.org/10.1525/jlin.1997.7.2.208

40. Sutrop, U. (2001). List task and a cognitive salience index. Field Methods, 13: 263-276. https://doi.org/ 10.117 7/1525822X0101300303

41. de la Torre, L., Cerón, C.E., Balslev, H. \& Borchsenius, F.A. (2012). Biodiversity informatics approach to ethnobotany: Meta-analysis of plant use patterns in Ecuador. Ecol Soc., 17:15. https://doi.org/ 10.5751/ES04582-170115

42. Thorn, J.P.R., Thornton, T.F., Helfgott, A. \& Willis, K.J. (2020). Indigenous uses of wild and tended plant biodiversity maintain ecosystem services in agricultural landscapes of the Terai Plains of Nepal. J Ethnobiol Ethnomed. 16:33. https://doi.org/ 10.1186/s13002-02000382-4

43. Tra Bi, F.H., Kouamé, F.N. \& Traoré, D. (2005). Utilisation of climbers in two forest reserves in West Côte d'Ivoire. In Forest Climbing Plants of West Africa. Diversity, Ecology and management. Bongers F, Parren MPE, Traoré D, (Eds). CABI publishing, Wallingford, 167-182

44. Tchoundjeu, Z. \& Atangana, A.R. (2007). Ricinodendron heudelotii (Baill.) Pierre ex Heckel. [On line] Protabase sheet. van der VOSSEN H.A.M. et MKAMILO G.S. (Eds). PROTA (Plant Resources of Tropical Africa), Wageningen, Netherlands. < http://database.prota.org/ recherche.htm>, (Consulted on, 12 August 2017.

45. Wondimu, T., Asfaw, Z., Kelbessa, E. (2006). Ethnobotanical study of food plants around 'Dheeraa' Town, Arsi, Ethiopia, Ethiop. J. Sci., 29:71-80. https:// doi.org/10.4314/sinet.v29i1.18261

46. Yao, K, Koné, M.W.\& Kamanzi, K. (2015). Contribution of leafy vegetables to the nutrition of populations in urban areas of the Côte D'ivoire. Eur. J. Sci. Res., 130:338-351 